\title{
METHODOLOGY OF TAFSIR AL-MUNIR WRITTEN BY AG. H. DAUD ISMAIL
}

\author{
Aswar Rifain ${ }^{1}$ \\ M. Rusydi Khalid ${ }^{2}$ \\ Hasyim Haddade ${ }^{3}$ \\ Muhyiddin Tahir ${ }^{4}$ \\ Ma'had Aly As'adiyah Sengkang Wajo Sulawesi Selatan ${ }^{1}$ \\ Fakultas Adab dan Humaniora UIN Alauddin Makassar ${ }^{2}$ \\ Fakultas Ushuluddin, Filsafat dan Politik UIN Alauddin Makassar ${ }^{3}$ \\ IAI As'adiyah Sengkang, Wajo Sulawesi Selatan ${ }^{4}$ \\ elrifain1992@gmail.com¹, rusydi.khalid@uin-alauddin.ac.id², \\ hasyim.haddade@uin-alauddin.ac.id ${ }^{3}$, muhyiddinwelle@gmail.com ${ }^{4}$
}

\begin{abstract}
This article elaborates the tafsir methodology used by local scholars, namely AG. Daud Ismail. This research is descriptive-analytic, which describes comprehensively the methodology of Tafsir al-Munir written by AG. H. Daud Ismail, which includes manhaj, sources, and tariqah (method). This research's primary and secondary sources are literature, which dominantly focuses on textbook research, especially Tafsir al-Munir in Buginese language written by AG. H. Daud Ismail. The results showed that Tafsir al-Munir used the tahlili methodology by explaining the relationship (munasabah) between verses or between one chapter and another. Explaining the causes of the descent (asbab al-nuzul), Analyzing vocabulary (mufradat) and the point of view of Arabic pronunciation from, Describing the general content of the verse, Explaining the fasahah elements, bayan and i'jaz, Explaining the laws that can be drawn from the discussed verse, Explaining the meaning and purpose contained on the verse which interpreted in fiqh style.
\end{abstract}

Keyword: Metodology; Tafsir Al-Munir; AG. H. Daud Ismail

\section{INTRODUCTION}

The activity of interpreting the Qur'an carried out since the period of the Prophet Muhammad SAW ${ }^{1}$ until the present because the activity of interpreting the Qur'an is an activity that does not consider the word end and tired. Moreover, the Qur'an gives authority to the Prophet Muhammad SAW to explain the revelation messages he received (QS al-Nahl/16:64).

The activity of interpreting the Qur'an has a long history involving many figures from the various ideology of Islam because after the Prophet Muhammad SAW died, the activities of interpreting the Qur'an did by the companions. ${ }^{2}$ In addition, the tabiin

الَّنِينَ 82

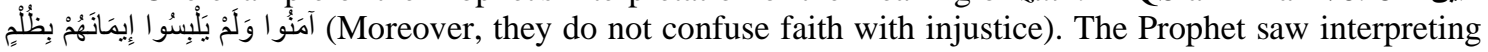
the word zulm in the context of this verse is shirk following the word of Allah SWT in QS Luqman/3:13

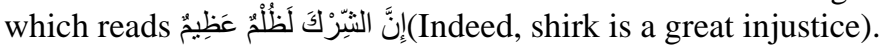

${ }^{2}$ The famous mufassir from among the companions were, Al-Khulafa' al-Rāsyidūn, Ibn Mas ' $\bar{u} d$, Ibn 'Abbās, Ubay bin Ka'b, Abū Mūsā al-Ash'ary, 'Abdullah bin Zubair, and those who were not well known were Ānas bin Mālik, Abū Hurairah, Abdullah bin 'Umar, Jābir bin 'Abdullah, 'Abdullah bin 'Amr bin al-'Ās, 'Āisyah. When viewed from the order of the companions who interpreted the Qur'an a lot, they 
and the scholars tried hard to interpret the Qur'an by producing various styles of interpretation and different methodologies.

The situation is in line with the development of Islam which is quite significant with the spread of Islamic politics to non-Arab areas. Many of the vocabularies of the Qur'an, which in the early days was quite clear, became blurred, ${ }^{3}$ poorly understood, or maybe even misunderstood. Therefore, the scholars must explain the arrangement of sentences or vocabulary not explained by the Prophet SAW or his friends. There was development in the field of interpretation of the Qur'an in changing times and problems faced by the mufassir. ${ }^{4}$

In general, the scholars of interpretation do not formulate the methodology they use. However, the results of the interpretation books study have understood that there were quite significant and varied methodology developments in interpreting the Qur'an, so that leading commentators have emerged from the past century from time to time with different styles and methods ${ }^{5}$ according to the knowledge possessed by the commentator.

The occurrence of various styles and methods of interpretation is usually because of the differences in the mission carried out, differences in motivation, differences in social society that surrounds or with differences in knowledge mastered, and the conditions and situations faced by the mufasir. ${ }^{6}$

Periodically the development and emergence of the interpretation of the Qur'an are divided into four periods. The al-Tafsiral-'Amali period, in the form of interpretation in direct practice from the Prophet SAW were continued by the friends and the tabiin. The al-Ta'wil al-Nazari period is an interpretation or disclosure of the meaning and intent of the verses of the Qur'an by using a ratio approach and relying a little on the history that comes from the Prophet Muhammad SAW. This period begins in the middle of the third century of Hijriyah, the period of al-Rukud (Stagnation), starting during the decline of the Abbasiyyah dynasty between 400-700 $\mathrm{H}$ and the period of al-TafsiralTatbiqi. This period occurred since the end of the XIX century. ${ }^{7}$

were Ibn Abbās, Ibn Mas'ūd, li bin Ab Talib and Ubay bin Ka'b. See Muhammad usain al-Żahabi, alTafsir wa al-Mufassirun, Juz I (Cet. II; t.t: Dar al-Kutub al-'Ilmiyah, 1976), h. 63-64. 355.

${ }^{3}$ Taufiq Adnan Amal, Rekonstruksi Sejarah Al-Qur'an (Yogyakarta: Pustaka Pelajar, 2001), h.

${ }^{4}$ Activities to understand and explain the contents of the Qur'an have existed at the beginning of Islam, namely at the time of the Prophet Muhammad himself. He is considered the first interpreter; the interpretation of the Qur'an by the Prophet Muhammad can be seen in various collections of hadith, which are usually entitled Kitab al-Tafsir.

${ }^{5}$ From the literature, there are several methods, namely talili, ijmali, muqāran and maudu' $i$, from these methods, giving rise to various styles, namely al-Sufi interpretation, al-fiqhi interpretation, al-falsafi interpretation, scientific interpretation, and adab al-ijtimā' $i$ interpretation, See Abd Hay al-Farmawi, alBidayah fi Tafsir al-Maudu 'i (Cairo: Maktabah Jumhu>riyyah, 1976), p. 23. See also S. Agil Husin alMunawar,I'jaz Al-Qur'an dan Metodologi Tafsir (Cet. I; Semarang: Dina Utama Semarang, 1994), h. 3637.

${ }^{6}$ Ignaz Goldziher, Mazahib al-Tafsir al-Islami, terj. M. Alaika Salamullah dkk., Mazhab Tafsir: dari Klasik Hingga Moderen (Cet. III; Yogyakarta: Elsaq Press, 2006), h. xi.

7،Affat al-Syarqawi, Qadaya Insaniyyah fi A 'mal al-Mufassirin (Cet. II; Bairut Dar al-Nahdah al-‘Arabiyyah, 1980),h. 14-15. 
In Indonesia, the Qur'an understanding is still lacking because Qur'an was in the Arabic language, ${ }^{8}$ scholars try to translate and interpret the Qur'an in Indonesian as well as in local languages to provide an understanding of the Qur'an to the public for Indonesian people in general and those who embrace Islam to make no longer any reason not to study and understand the meaning of the Qur'an.

The activities of translating and interpreting the Qur'an existed for quite a long time with the diversity of local languages used. The emergence of interpretive literature in various local languages such as Malay, Javanese, Buginese, and other local languages. ${ }^{9}$ The commentators (mufasir) compiled interpretations with various types of language and methods used.

In South Sulawesi, the activities of interpreting the Qur'an into the Buginese language have happened by the Buginese Muslim scholars such as those carried out by AG. H. Abd. Muin Yusuf interprets 30 juz of the Qur'an, AG. H. M. Yunus Martin, who interpreted several juz al-Qur'an, AG. H. Kadir Khalid MA. interpret juz 'amma, AG. H. Sade' who interprets juz 'amma, and AG. H. Daud Ismail, who interprets 30 juz.

The existence of Buginese language interpretations written by Muslim scholars is beneficial for Muslims to understand the Qur'an. This effort is made more accessible with the lontara script, which is the Buginese alphabet. ${ }^{10}$ Socio-culturally, Tafsir alMunir was born in Buginese society, and the use of Buginese language as the daily language of instruction. In addition, the formulation of the interpretation of the Buginese language is to preserve the Buginese language from extinction and provide a correct understanding of several traditions that are contrary to the teachings of Islam that are still maintained.

\footnotetext{
${ }^{8} \mathrm{Not}$ all of the vocabulary in the Qur'an comes from Arabic. There is a small portion that is not derived from Arabic/'Ajamiyah; this cannot change the position of the Qur'an as a clear Arabic language. Muhammad 'Ali al-Sabuni, al-Tibyan fi 'Ulum al-Qur'an (Bairut: Dar al-Fikr, 1978), h. 40.

${ }^{9}$ Hamzah Fansuri is one of the scholars who is considered to have first translated the Qur'an in Malay who lived in 1550-1599; although no commentary works are identified with him, in his prose and poetry, Hamzah translated the Qur'an into beautiful Malay language. One excellent example of one of his four-line poems against QS al-Ikhlas is that the sea is called ahad, it is too complete in al-Shamad, by which it is lam yalid walam yūlad walam yakun lahu kufuan ahad, see Anthoni H Johns, "Tafsir al-Qur'an in the Malay Indonesian World: An Initial Research," in the Journal of the Study of the Qur'an, Vol. I, No 3, 2006, h. 46.
}

${ }^{10}$ Lontara script (for Buginese language) consists of 23 letters:

$\begin{array}{llllllll}\mathbf{k} & \mathbf{g} & \mathbf{G} & \mathbf{K} & (\mathbf{k a} & \text { ga } & \text { nga } & \text { ngka }) \\ \mathbf{p} & \mathbf{b} & \mathbf{m} & \mathbf{P} & (\mathbf{p a} & \mathbf{b a} & \text { ma } & \mathbf{m p a}) \\ \mathbf{t} & \mathbf{d} & \mathbf{n} & \mathbf{R} & (\mathbf{t a} & \mathbf{d a} & \text { na } & \text { nra }) \\ \mathbf{c} & \mathbf{j} & \mathbf{N} & \mathbf{C} & (\mathbf{c a} & \mathbf{j a} & \text { nya } & \text { nca }) \\ \mathbf{y} & \mathbf{r} & \mathbf{l} & \mathbf{w} & (\mathbf{y a} & \text { ra } & \text { la } & \text { wa }) \\ \mathbf{s} & \mathbf{a} & \mathbf{h} & & (\mathbf{s a} & \mathbf{a} & \text { ha }) & \end{array}$

Anthropologists have different opinions regarding the origin of the Bugis lontara script; for example, Mattulada, stating that the lontara' script stems from the beliefs and mythological views of the Bugis-Makassarese people who view the universe as sulp aEp lw soji (a quadrangle of diamonds). This natural animal is a unit expressed in the symbol "s," which means esauw (one or single). So this is where the sound signs in the lontara' script come. Mattulada, Latoa: Satu Lukisan Analitis terhadap Antropologi Politik Orang Bugis (Yogyakarta: Gajah Mada University Press, 1985), h, 8-9. 
One of the interpretations in the Buginese language (aogi) which will be the focus of research in this thesis is" تـرجمــة وتفسير trujum nEniy tpEeser (Translation and Tafsir), then changed to Tafsir al-Munir. Tafsir al-Munir is the first complete tafsir in Buginese language 30 juz written by AG. H. Daud Ismail, a charismatic Islam scholar from Soppeng Regency, South Sulawesi.

Tafsir al-Munir began to be written around the 1980s by AG. H.David Ismail. In terms of the periodization of its development, this interpretation belongs to the category of contemporary interpretation. However, when viewed from the perspective of interpretation, it is still classified as textual. Likewise, from the methodological aspect, it still follows the pattern of interpretation adopted by previous interpreters. However, this interpretation still has its characteristics compared to the interpretation, which is the primary reference.

The effort to understand the work of interpretation as a product in the context of its socio-historical struggle is a fascinating study. Therefore the author is interested in researching the work of the tafsir above. In this study, it is necessary to have a clear conception of variables to identify the characteristics inherent in a work of tafsir.

\section{Method}

This research is descriptive-analytic, which describes comprehensively the methodology of Tafsir al-Munir written by AG. H. Daud Ismail, which includes manhaj, sources, and tariqah (method). This research's primary and secondary sources are literature, which dominantly focuses on textbook research, especially Tafsir al-Munir in Buginese-language written by AG. H.David Ismail.

\section{Research Results and Discussion}

\section{A. The Author of Tafsir Al-Munir}

\section{His Family Background}

The full name of the compiler of Munir's commentary in the Buginese language is AG. H. Daud Ismail is often called H. Dauda or AG. H. Daud Ismail by the nickname kali $^{11}$ Soppeng, which is related to the position of AG. H.Daud Ismail. AG. H. Daud Ismail was born on December 30, 1908M in Cenrana Soppeng regency. Her father is $\mathrm{H}$. Ismail bin Baco Poso, a farmer, katte, and also a teacher of the Qur'an, and her mother is Hj. Pompala bint Latalibe, as a housewife. Both of his parents are respected people and community leaders.

During his lifetime, AG. H. Daud Ismail had three wives. First, with $\mathrm{Hj}$. Marellung in 1932. His marriage with Hj. Marellung, AG. H. Daud Ismail was blessed with two sons, H. Ahmad Daud and H. M. Basri Daud, Lc. After his first wife died, AG. H. Daud Ismail married $\mathrm{Hj}$. Salehah. However, during this marriage, AG. H. Daud Ismail was not blessed with children. Then, AG. H. Daud Ismail held his third marriage

${ }^{11}$ The word kali comes from the word qadi (judge), but in Bugis language, it is broader in scope than just a judge who decides cases. Kali is an essential position as the king's partner in religious matters, not only in court matters but also includes marriage, divorce, inheritance, zakat, and the settlement of social problems related to syara' law and customary law, which includes speech (legal norms), rapang (exemplary norms), wari (social stratification) and syara' (Islamic law), read more about Mattulada, Latoa: Satu Lukisan Analitis terhadap Antropologi Politik Orang Bugis (Yogyakarta: Gajah Mada University Press, 1985), h. 275. 
with $\mathrm{Hj}$. Faridah in 1942 and was blessed with three children, each named $\mathrm{Hj}$. Syamsul Huda, Hj. Nur Inayah and Drs. H. M. Rusydi Daud. ${ }^{12}$ On Monday, August 21, 2006, in Hikmah Hospital Makassar at the AG. H. Daud Ismail died at the age of 99 years accompanied by his third wife. ${ }^{13}$ AG. H. Daud Ismail was being buried at the Yasrib Watansoppeng Islamic Boarding School.

2. His Educational Background

AG. H. Daud Ismail grew up under his parents' direct supervision and upbringing, who are also community leaders. At a young age, AG. H. Daud Ismail has shown his perseverance, intelligence, and attention to science and learning to read Buginese lontara on a self-taught. AG. H. Daud Ismail, being known as a scholar of interpretation through his book Tafsir al-Munir which was written in Buginese lontara language, is also known as an expert in various other religious disciplines.

His love in science made AG. H. Daud Ismail moved from one area to another to study Religion. Here are some scholars where AG. H. Daud Ismail added the knowledge of Religion:

a) Haji Muhammad Salih, Imam Lompo in Cangadi, Liliriaja District, Soppeng regency;

b) H. Ismail (Qadhi Soppeng).

c) Guru Tengnga in Ganra.

d) Haji Syamsuddin Imam Sengkang.

e) Haji Daeng Sumange in Ceppie Village Soppeng Riaja.

f) Haji Kitta (Qadhi Soppeng Riaja).

g) H. Muhammad As'ad Sengkang.

Lastly, AG. H. Daud Ismail went to Sengkang to study Religion from one of the scholars who returned to his homeland to spread the knowledge of Religion after completing his education in Mecca, namely al-'Alim al-'Allamah al-Shaykh KHM As'ad al-Buqisi Muslim scholar who famous with his knowledge. Since then, gurtta Daud studied with gurutta As'ad directly and settled in Sengkang.

Besides studying, AG. H. Daud Ismail is trusted to teach at the Ibtidaiyah and Tsanawiyah levels. Since then, AG. H. Daud Ismail is called gurutta. ${ }^{14}$

In 1952, after the death of Gurutta As'ad. The community of Wajo and the administrators of the Madrasah 'Arabiyah Islamiyah (MAI) ${ }^{15}$ agreed to ask AG. H. Daud Ismail returned to Sengkang to replace al-'Alim al-'Allamah al-Shaykh K. H. M. As'ad al-Buqisi, who had died, to conduct coaching at the madrasa. From 1953 to 1961, AG. H. Daud Ismail continued the struggle while leading the madrasa left by al-'Alim

${ }^{12}$ Susdiyanto, “AG. H. Daud Ismail; Ulama Kharismatik dari Soppeng," in H. Muh. Ruslan and Waspada Santing, eds., Ulama Sulawesi Selatan; Biografi Pendidikan dan Dakwah (Cet. I; Makassar: Komisi Informasi dan Komunikasi MUI Sulawesi Selatan, 2007), h. 137. 2017), h. 43.

${ }^{13}$ Muhammad Firdaus, Anregurutta: Literasi Ulama Sulselbar (Makassar; Nala Cipta Litera,

${ }^{14}$ The word gurutta is a title given to the ulema of South Sulawesi. It's the same with the title of Kyai in Java, Tuan Guru in West Nusa Tenggara, Buya in Minang. Furthermore, the title gurutta is divided into two. Namely, Senior is called Anre Gurutta (AG), and Junior is called Gurutta (Grt).

${ }^{15}$ Madrasah 'Arabiyah Islamiyah (MAI) is a madrasa founded by al-'Alim al-'Allamah al-Shaykh K. H. M. As'ad al-Buqisi in 1930 in the city of Sengkang, Kab. Wajo, which is now known as As'adiyah Sengkang Islamic Boarding School. 
al-'Allamah al-Shaykh K. H. M. As'ad al-Buqisi. ${ }^{16}$ During the leadership of AG. H. Daud Ismail, the name of Madrasah 'Arabiyah Islamiyah (MAI), was changed to Madrasah As'adiyah (MA) in 1953 as a tribute and appreciation to the founder of the madrasa. ${ }^{17}$

Al-'Alim al-'Allamah al-Shaykh K. H. M. As'ad al-Buqisi acknowledged the knowledge and love of AG. H. Daud Ismail in science. As Gurutta Amin Ganra once said.

"kEnai nsEeG gurut hji sdE mkEdea aiyro gurumu daudE mklel ldE nsb bias ntbai pdisEGEeG nsb nerko ritnawii ed necdimi pepblin wEdi mto mpkuea wEdimto mpkuea." 18

It means:

"As AG. H. Muhammad As'ad said, "Your teacher Daud is different from the others because he often adds our knowledge. When we asked him, he answered not only one answer. It can be like this or that."

From here, the breadth of AG. H. Daud Ismail's knowledge can be understood when asked him a question, AG. H. Daud Ismail did not answer with one answer but used muqaran (comparison) by quoting the opinions of other scholars.

One proof of AG. H. Daud Ismail's love of science is Tafsir al-Munir's existence in the Buginese language $30 \mathrm{Juz}$, which did not exist before in the Bugis area.

3. His works

The works of AG. H. Daud Ismail has shown as follows:

a) Pengetahuan Dasar Agama Islam as much as 3 volumes. This book discusses the basic knowledge of Islam which includes the pillars of faith and the pillars of Islam.

b) Al-Ta'rif bi al-'Alim al-'Allamah al-Shaykh al-Haj Muhammad As'ad alBuqisi. This book contains the biography of AG. H. Muhammad As'ad, one of the teachers of AG. H. Daud Ismail who lives in Sengkang City, Wajo regency, South Sulawesi.

c) bicrn nikea (Marriage Case) talks about the laws of marriage.

d) bicrn sEPjeG (Prayer Matters) this book contains prayer matters such as the meaning of prayer, fardu prayers, sunnah prayers, and the importance of praying in congregation.

e) Kumpulan do'a dalam kehidupan sehari-hariKumpulan khutbah jum'at berbahasa bugis

${ }^{16}$ The order of leadership in As'adiyah began to be established: 1. al-'Alim al-'Allamah al-Syaikh K. H. M. As'ad al-Buqisi. 2. AG. H. Ambo Dalle. 3. AG. H. Muh. Yunus Martang. 4. AG. H. Hamzah Badawi. 5. AG. H. Abd. Malik Muhammad. 6. AG. H. Abd. Rahman Musa. 7. AG. Prof. Dr. H. M. Rafi'i Yunus Martang, MA. 8. AG. Drs. H. Muhammad Sagena, MA

${ }^{17}$ M. Rafii Yunus Martan, Membidik Universalitas, Mengusung Lokalitas; Tafsir al-Qur'an Bahasa Bugis Karya AG. H. Daud Ismail, dalam Jurnal Studi al-Qur'an. Vol. I, No. 3 (Ciputat; PSQ, 2006), h. 525.

${ }^{18}$ Gurutta Amin, one of Gurutta As'ad's students and a student and companion of Gurutta Daud, has served as the Head of the Ganra Islamic Boarding School Kab. Soppeng. Interview on 25 April 2011 in Ganra Kab. Soppeng. in Muhyiddin,Tafsir al-Munir (Studi atas Pemikiran Akhlak AG. Daud Ismail). Disertasi (Makassar, PPs UIN Alauddin, 2012),h. 67. 
f) Kumpulan do'a sehari-hari

\section{B. Getting to Know Tafsir Al-Munirs}

\section{Background of Tafsir al-Munir writing}

The background of AG. H. Daud Ismail compiled the book of Tafsir alMunir has several reasons. As stated by AG. H. Daud Ismail in his preamble Volume I, Juz I.

"naiy sbn nwktktai susuGi aiyea kitea eswea kit mbs augi.",19

It means:

"As for a reason, I compiled this book. A book in Buginese language."

a. As I have noticed in the Bugis area, there is no complete Bugis interpretation of the Qur'an in $30 \mathrm{Juz}$ which can be a representation of the work of interpretation for the Bugis area and can be read by Muslims ${ }^{20}$ especially in Bugis land.

b. So that the Buginese can understand the Qur'an because they read it using their language (Bugis). ${ }^{21}$ It is undeniable that not everyone can understand the Qur'an directly well because the Qur'an is in Arabic ${ }^{22}$. The existence of this Bugis-language interpretation can help Bugis people understand the meanings of the Qur'an, especially for people who are unable to understand Arabic (al-Qur'an and Arabic commentary books) and Indonesian (translated al-Qur'an) well.

c. It is information to other tribes in Indonesia that the Buginese language can interact with Arabic, ${ }^{23}$ because it has its script known as the Lontara script and its own rules. Many Indonesians do not know that the Buginese language has its lontara letters and language rules because the Bugis themselves did not introduce their language and script to other tribes.

d. To make this tafsir can be a guide for the next generation, according to AG. H. Daud Ismail, the verses of the Qur'an may have been translated or interpreted into various languages, but it cannot represent what is contained in the language of the Qur'an ${ }^{24}$ because in the Qur'an there are mujmal and mubayyan words, mutlaq, and muqayyad, am and khas and others. If someone has mastered some of the tools used to interpret the Qur'an verses, such as Nahwu, sarf, usul fiqh, and balagah, as well as the relevant sciences, could be known.

e. To keep the existence of the Buginese language. As stated by AG. H. Daud Ismail," as I have noticed, there are still many Bugis people who

${ }^{19}$ AG. H. Daud Ismail, Tafsir al-Munir, Jilid I(Ujung Pandang, Bintang Selatan, t.h.), h. 4.

${ }^{20}$ AG. H. Daud Ismail, Tafsir al-Munir, h. 4-5.

${ }^{21}$ AG. H. Daud Ismail, Tafsir al-Munir, h. 5.

${ }^{22}$ QS al-Syu'ara'/26:195.

${ }^{23}$ AG. H. Daud Ismail, Tafsir al-Munir, h. 5.

${ }^{24}$ AG. H. Daud Ismail, Tafsir al-Munir, h. 6. 
have not been able to read the Bugis lontara script". ${ }^{25}$ In line with the author's observation that many young people cannot read Bugis lontara script.

AG. H. Daud Ismail's hope when he began to compose his tafsir, it could give a result. There has been a request to be printed while the interpretation process until 30 juz was not done yet. Revealed by AG. H.David Ismail:

"sitoGEtoGEn ribuGE aupmulain trEjumai/tpEeserai akor mlEbiea, naiy aktku sokupi autpEeser tElupulo jusE nainpai auwsuro ectai. neakiy aEK saisn sielsurE sElEku emlauwi serko amEGi jusE $\square \square$ riect mtuKEai. "26

It means:

"Actually, in the beginning, I was translating/interpreting al-Qur'an al-Karim; I intended to finish until the 30th juz and then to be printed. However, some of the Muslims in the Buginese area requested that 30th juz could be printed separately."

It is deemed necessary to do this as soon as possible because the surah in the 30th juz is the surah often used in prayer to help Muslims understand what is read in prayer with this Buginese translation/interpretation of the Qur'an (tafsir al-Munir).

2. Physical Appearance of al-Munir's Tafsir

When the first time this tafsir was printed, the format was each juz of the Qur'an that was translated or interpreted was printed in one juz of one volume. ${ }^{27}$ It is different from the current printed; each volume has three chapters. Previously there were 30 volumes of 30 juz, now 10 volumes of 30 juz.

In the preamble of the IV printing, which is now AG. H. Daud Ismail stated the reason for the print that combines three juz (chapter) of the al-Qur'an in one volume with a hardcover (thick skin). AG. H. Daud Ismail says:

"naiy riect bruea rijiliai mauPE pkulin, serkuamEGi nmait th. naiy sitEmErEeG akor ripCjiwi sEpulo jili, ntElu jusE esdi jili." 28

It means:

"The reason to bind the new one with a hardcover is to make it long last. 30 juz (chapters) 10 volumes, each volume contains three juz."

3. Maraji' Tafsir al-Munir

A book of tafsir (interpretation) cannot be separated from the source (masadir) used by the author, in this case, AG. H. Daud Ismail revealed the references used in his commentary at the end of each volume of this tafsir, namely Tafsir al-Maragikarya by Ahmad Mustafa al-Maragi, Tafsir al-Jalalain by Jalaluddin Muhammad bin Ahmad al-

${ }^{25}$ AG. H. Daud Ismail, Tafsir al-Munir, h. 6.

${ }^{26}$ AG. H. Daud Ismail, Tafsir al-Munir, Jilid 10, Juz 30, h. 9.

${ }^{27}$ M. Rafii Yunus Martan, Membidik Universalitas, Mengusung Lokalitas; Tafsir al-Qur'an Bahasa Bugis Karya AG. H. Daud Ismail, dalam Jurnal Studi al-Qur'an, h. 531.

${ }^{28}$ AG. H. Daud Ismail, Tafsir al-Munir, Jilid 4, Juz 10, h. ii. 
Mahalli and Jalaluddin 'Abd. Rahman al-Suyuti and al-Qur'an and their translation were published by the Indonesian Ministry of Religion.

Even though AG. H. Daud Ismail mentions the references used on his tafsir, sometimes AG. H. Daud Ismail quotes interpretations from other tafsir when AG. H. Daud Ismail explains the stages of hell by quoting ibn Jarir's tafsir. ${ }^{29}$

\section{Methodology of Tafsir al-Munir}

1. The form of interpretation in Tafsir al-Munir

The form of interpretation in Tafsir al-Munir is classified as tafsir bi al$M a{ }^{\prime}$ sur, ${ }^{30}$ clearly seen on the statement of AG. H. Daud Ismail "naiy akoreG saisnmuto tpEeserai saisn" (The Qur'an interprets part of the Qur'an itself).

Most of the interpretations in tafsiral-Munir by AG. H. Daud Ismail was interpreted the Qur'an using the arguments of the Qur'an, hadith, friends, and tabi'in. It can be seen from the following examples:

a) The interpretation using verses of the Qur'an

In his interpretation AG. H. Daud Ismail uses the verses of the Qur'an found in QS al-Baqarah; 2/10.

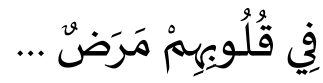

The translation:

"on their hearts, there is a disease..." 31

AG. H. Daud Ismail interprets the above verse using the verse of QS al-A'raf; 7/179.

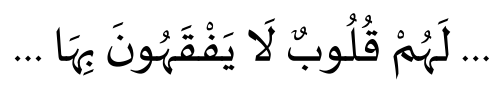

The translation:

"...they have hearts, but they are not used to understand (the verses of Allah)...". ${ }^{32}$

b) The Interpretation using Hadith

In the Qur'an QS al-Taubah; 9/38

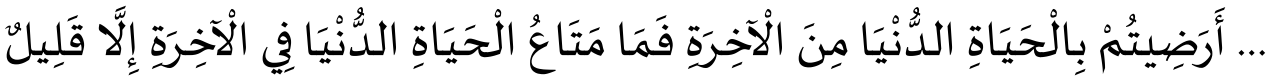

\footnotetext{
${ }^{29}$ AG. H. Daud Ismail, Tafsir al-Munir, Jilid 5, Juz 14, h. 38.
}

${ }^{30}$ Tafsirbi al-Ma'sur is an interpretation of the verses of the Qur'an using the sources of the Qur'an, hadith, the interpretation of friends, and tabi'in. See Fahd 'Adbdurrahman al-Rumi, Buhus fi Usul al-Tafsir wa Manahijuh, p. 73-78. See also M. Quraish Shihab, Rules of Tafsir, p. 349-351. In the book Manahil al-'Irfan fi 'Ulum al-Qur'an volume II, page 11 by Imam al-Zarqani mentions that there are three sources of interpretation of bi al-Masur: 1) al-Qur'an 2) Hadith 3) Interpretation of friends.

${ }^{31}$ Kementerian Agama Republik Indonesia, Al-Qur'an dan Terjemahnya, h. 3.

${ }^{32}$ Kementerian Agama Republik Indonesia, Al-Qur'an dan Terjemahnya, h. 174 
The translation:

"...are you pleased with the life of this world rather than the Hereafter? Nevertheless, little is the enjoyment of the life of this world as compared with the Hereafter." 33

AG. H. Daud Ismail when interpreting the problem of enjoyment in verse above quotes a hadith narrated by imam Muslim, Ahmad, and Tirmizi

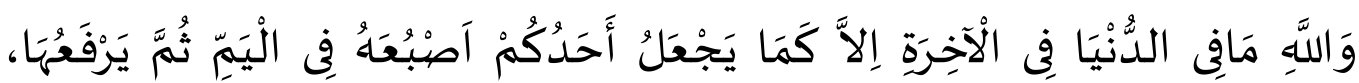

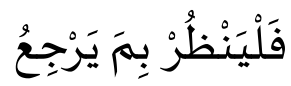

bEtuwn:

"naEK puaaltal edai sinin (aNmE NmEGE aEKea) rilino (nreko aibdiGi sibw aNmE NmEGE aEKea) riaehr. sGdin pdmi eswea tau mjEjEkEeGGi krem limn rillEn tsiea. nainpni nkai/nwtai krem limn ritu (poel ritsiea) pErEhtikGi ritu siag (tEtin auwea npeaeR). ${ }^{34}$

It means:

"For the sake of Allah, there is no (joy of life) in this world and (pleasure of life) in the hereafter except like the example of a person who dips his fingers into the ocean, then pulls his fingers back, then watch how many drops of water are falling."

The above hadith describes the parable of the pleasures in this world and the pleasures in the hereafter, with the example of a person dipping his fingers into the ocean and then pulling them back. Every drop of falling water is life's pleasure in this world, while the water still in the ocean is the pleasure of the hereafter.

c) The Interpretation using the Opinion of Friends

Interpretation using the opinion of friends can be seen in QS al-Baqarah; 2/71.

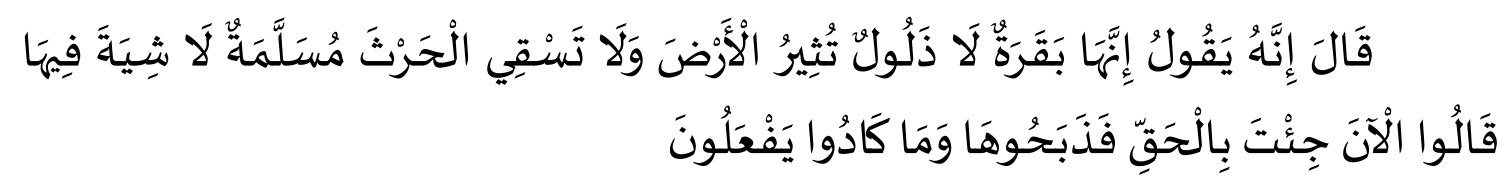

The translation:

"He (Moses) said," He says, 'it is a cow neither trained to till the soil nor water the fields, sound, having no other colour except bright yellow.' "They said, "Now you have brought the truth. "So they slaughtered it though they were near to not doing it." 35

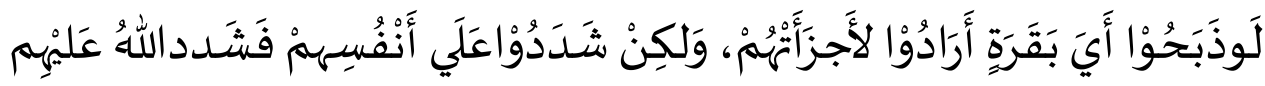

\footnotetext{
${ }^{33}$ Kementerian Agama Republik Indonesia, Al-Qur'an dan Terjemahnya, h. 193.

${ }^{34}$ AG. H. Daud Ismail, Tafsir al-Munir, Jilid 10, h. 137.

${ }^{35}$ Kementerian Agama Republik Indonesia, Al-Qur'an dan Terjemahnya, h. 11.
} 
bEtuwn:

"ebeneGnegerai epgepg spi aiy pd npuealoea egerai mjEpu mmdaini, naiykiy pd mepsEroai riaeln mEnRo, nrieptEREkiton mEnRo ripuw altal. "'36

It means:

"If they slaughter whatever cow they want, then the slaughter is sufficient/valid, but they burden themselves (with many questions) then Allah SWT burdensome requirements."

Although in tafsir al-Munir interpretation using bi al-Ma'sur approach, it is possible for AG. H. Daud Ismail also uses bi al-Ra'y approach.

2. The method of interpretation in Tafsir al-Munir

a) Approach Method

The viewpoint of the interpretation approach used by AG. H. Daud Ismail, it can be said that the method used in his interpretation is the tahlili method. The interpreter tries to explain the relationship (munasabah) between one verse and another and between one surah and another. Explain the causes of its descent (asbab al-nuzul), Analyzing vocabulary (mufradat) and pronunciation from the point of view of the Arabic language, Explaining the content of the verse in general, Explaining the elements of fashah, bayan, and its $i^{\prime} j a z$, Explaining the laws that can be used drawn from the verse being discussed, Explaining the meaning and intent contained in verse being interpreted. ${ }^{37}$ It can be seen from the interpretation of AG. H. Daud Ismail, before interpreting surah al-Kafirun, AG. H. Daud Ismail firstly revealed (sbn nturu aiyea surea) the reason for the descent of the $\operatorname{surah}^{38}$ or AG. H. Daud Ismail revealed (sbn nturu aiyea ayea) the reason for the revelation of the verse. ${ }^{39}$ It also can be seen when AG. H. Daud Ismail interprets the word ينفقون in QS al-Baqarah; 02/3 nekloriea ablC ynritu iaiy lEbeGGi blC wjiea nEniy blC sunea" 40 (what is meant by "shopping" is obligatory and sunnah shopping).

Even though he uses the tahlili method in his tafsir, it is possible that AG. H. Daud Ismail uses another method.

b) The style of interpretation in Tafsir al-Munir

Meanwhile, if viewed from the style of interpretation, tafsir al-Munir by AG. H. Daud Ismail is a type of fiqhi, which can be seen from the interpretation of AG. H. Daud Ismail when interpreting at length the verses related to fiqh. This can be seen when AG. H. Daud Ismail interprets the word أقيموا الصلاة in QS al-Baqarah;

${ }^{36}$ AG. H. Daud Ismail, Tafsir al-Munir, Jilid 1, Juz 1, h. 105.

${ }^{37}$ M. Quraish Shihab, dkk., Sejarah dan Ulum Al-Qur'an (Jakarta: Pustaka Firdaus, 2008), h. 172.

${ }^{38}$ AG. H. Daud Ismail, Tafsir al-Munir, Jilid 10, Juz. 30, h. 307.

${ }^{39}$ AG. H. Daud Ismail, Tafsir al-Munir, Jilid 10, Juz. 28, h. 10.

${ }^{40}$ AG. H. Daud Ismail, Tafsir al-Munir, Jilid 1, h. 54. 
c) The Systematics of interpretation in Tafsir al-Munir

In general, each commentator has its systematics in writing his commentary to make it easier for readers. If you pay attention to tafsiral-Munir by AG. H. Daud Ismail, it can be concluded that AG. H. Daud Ismail, writing his tafsir, used the following systematics:

1) Introduction, when AG. H. Daud Ismail was interpreting the Qur'an at the beginning of every juz; he always stars with an introduction as a sign of gratitude for the presence of Allah SWT by hoping that the expectation reaches by the readers, however on the first juz as well as the first volume, before AG. H. Daud Ismail begins his introduction he mentions things that need attention for the reviewers of the Qur'an.

2) AG. H. Daud Ismail always started his interpretation when he was at the beginning of a surah; he suggested juz (chapter) and surah be interpreted and stated the number of verses in the surah to be interpreted in Buginese lontara writing.

Jus E 28

$$
\text { سورة المجادلة }
$$

sur mlimpuloea aruw. 22 ayn

3) Putting the verse on the right and the translation of the verse on the left.

\begin{tabular}{|c|c|}
\hline $\begin{array}{l}\text { Naiy ad medeceG nEniy } \\
\text { adPEGEeG msEro edecGi naiy } \\
\text { psidEk nkcoewriea peppEdi } \\
\text { (ripepnEdin tau riewereG). Naiy } \\
\text { pua altal msEro sugiai nmrj NmE } \\
\text { kininw. }\end{array}$ & 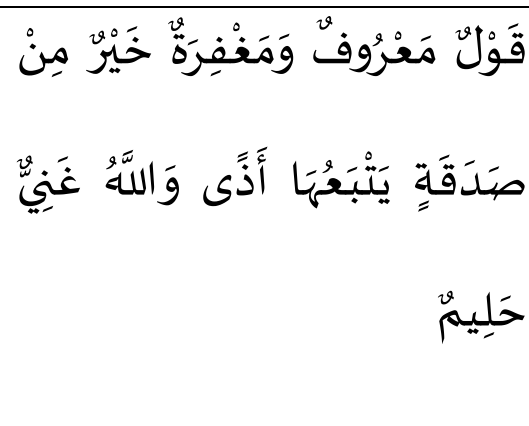 \\
\hline
\end{tabular}

According to AG. Rafii Yunus Martan: with such a format, the neatness of the layout of this tafsir can be maintained. When the reader reads the tafsir, they immediately understand that this format is the format for the translation of the verses of the Qur'an. ${ }^{41}$

4) The Qur'an verses interpretation is carried out after the verses of the Qur'an and translation with the expression "ppktjn" (its interpretation).

At the end of each juz (chapter), there is always a table of contents to make it easier.

${ }^{41}$ M. Rafii Yunus Martan, Membidik Universalitas, Mengusung Lokalitas; Tafsir al-Qur'an Bahasa Bugis Karya AG. H. Daud Ismail, dalam Jurnal Studi al-Qur'an. Vol. I, No. 3. H. 533. 


\section{IV.CONCLUSION}

Based on the explanation above, it can be concluded that Tafsir al-Munir uses the tahlili methodology by explaining the relationship (munasabah), both between one verse and another or between one surah and another. Explaining the causes of its descent (asbab al-nuzul), Analyzing vocabulary (mufradat) and pronunciation from the point of view of the Arabic language, Explaining the content of the verse in general, Explaining the elements of Fasahah, Bayan and its i'jaz, Explaining the laws that can be used drawn from the verse being discussed, explaining the meaning and purpose contained in interpreted verse by the fiqh style.

\section{REFERENCES}

Amal, Taufiq Adnan, Rekonstruksi Sejarah Al-Qur'anYogyakarta: Pustaka Pelajar, 2001.

Anthoni H Johns, “Tafsir al-Qur'an di Dunia Indonesia Melayu: Sebuah Penelitian awal," dalam Jurnal Study Al-Qur'an, Vol. I, No 3, 2006.

Farmawi, Abd Hay al-, al-Bidayah fi Tafsir al-Maudu'i Kairo: Maktabah Jumhuriyyah, 1976.

Firdaus, Muhammad, Anregurutta: Literasi Ulama Sulselbar Makassar; Nala Cipta Litera, 2017.

Goldziher, Ignaz, Mazahib al-Tafsir al-Islami, terj. M. Alaika Salamullah dkk., Mazhab Tafsir: dari Klasik Hingga ModerenCet. III; Yogyakarta: Elsaq Press, 2006.

Ismail, AG. H. Daud, Tafsir al-Munir, Jilid IUjung Pandang, Bintang Selatan, t.h.

Martan, M. Rafii Yunus, Membidik Universalitas, Mengusung Lokalitas; Tafsir alQur'an Bahasa Bugis Karya AG. H. Daud Ismail, dalam Jurnal Studi al-Qur'an. Vol. I, No. 3 Ciputat; PSQ, 2006.

Mattulada, Latoa: Satu Lukisan Analitis terhadap Antropologi Politik Orang Bugis Yogyakarta: Gajah Mada University Press, 1985.

Muhyiddin, Tafsir al-Munir (Studi atas Pemikiran Akhlak AG. Daud Ismail). Disertasi Makassar, PPs UIN Alauddin, 2012.

Munawar, S. Agil Husin al-, I'jaz Al-Qur'an dan Metodologi TafsirCet. I; Semarang: Dina Utama Semarang, 1994.

Rumi, Fahd 'Adbdurrahman al-, Buhus fi Usul al-Tafsir wa Manahijuh, h. 73-78. Lihat juga M. Quraish Shihab, Kaidah Tafsir,

Sabuni, Muḥammad 'Ali al-, al-Tibyan fi 'Ulum al-Qur'anBairut: Dar al-Fikr, 1978.

Shihab, M. Quraish, dkk., Sejarah dan Ulum Al-Qur'anJakarta: Pustaka Firdaus, 2008. 
Susdiyanto, "AG. H. Daud Ismail; Ulama Kharismatik dari Soppeng," dalam H. Muh. Ruslan dan Waspada Santing, eds., Ulama Sulawesi Selatan; Biografi Pendidikan dan Dakwah Cet. I; Makassar: Komisi Informasi dan Komunikasi MUI Sulawesi Selatan, 2007.

Syarqawi, 'Affat al-, Qadaya Insaniyyah fi A'mal al-Mufassirin Cet. II; Bairut Dar alNahdah al-'Arabiyyah, 1980.

Żahabi, Muhammad Husain al-, al-Tafsir wa al-Mufassirun, Juz I Cet. II; t.t: Dar alKutub al-'Ilmiyah, 1976. 